\title{
The Relationship between Reward, Work Discipline, Motivation and Employee Job Satisfaction among Employees of Inews Tv Padang, Indonesia
}

\author{
Dorris Yadewani, Reni Wijaya
}

\begin{abstract}
This study aims to analyze the influence of reward, motivation and discipline to employee job satisfaction. The sample of this research is 15 employees of iNews TV. Exploratory factor analysis aims to confirm the structure of factors that underlie independent predictors with each other. The results of this study explain that reward, motivation and work discipline affect job satisfaction reward, motivation and work discipline affect job satisfaction. Of the several variables that affect job satisfaction, the work discipline variables that provide the greatest contribution to satisfaction.Company management is expected to pay attention to variable work discipline employees to support the achievement of job satisfaction
\end{abstract}

Index Terms: Reward, Motivation, Work Discipline and Job Satisfaction

\section{INTRODUCTION}

According to organizational behaviour perspective, job satisfaction is often seen as a result of employees' perception or appraisal of their job (Azman, 2014).Job satisfaction is defined as The degree to which employees are generalyy statisfied wich their work.(Senasu \& Singhapakdi, 2014).Job satisfaction is an important target in human resource management because it can affect the performance and productivity of labor as evident from how employees react to changes in the characteristics of his work(Mangkunegara \& Octorend, 2015). As such, job satisfaction reflects employee perceptions of job performance, i.e. employees with high levels of job satisfaction will feel that they are contributing positively value and outcomes to the organization. They also feel that they have a clear understanding of their job contribution.In addition, satisfied employees tend to perceive that they are treated fairly both inside and outside of an organization. To conclude, employees' positive perceptions of their jobs and their organization can be revealed through job satisfaction.(Choi, Goh, Adam, \& Tan, 2016).

Problems faced by iNews Tv employees are the low return earned so that employees have no hope of working in the company. Reward is an important function of human resource management where it is given to individuals as

Dorris Yadewani, Study Program: Information and Computer Management, AMIK Jayanusa, Indonesia, dorris290@gmail.com

Reni Wijaya, recognition of service, effort or achievement (Azman, 2014) The provision of reward reflects the organization's efforts to maintain and improve the employees welfare andto motivate them to work harder.

In addition, in the enforcement of discipline against employees is still very lacking as its past application have not provided decisive action against employees who violate the rules. Such phenomenom impact on productivity and morale to work especially for employees who show high level of discipline. As such, work discipline is an attitude and behavior that shows employees employees' obedience to organizational rules (Finna Okta Maulina, Yusuf, \& Priyatama, 2015)

So also in the provision of motivation provided by the company, especially leaders who are still very limited as just provide motivation to employees just so that employees who have long worked in the company feel reluctant or less responsible for the work that is charged to him. In addition motivation means a concept that is used to describe an encourage that is appear in one's self in order to move and lead their attitude (Sari, R.F., Siburian, T.A, \& Wau, 2017)

As such, this exploratory study aims to test whether reward, motivation and work discipline affect employee job satisfaction at iNews Tv Padang company. A subyek of 15 employees will be used for this study.

\section{LITERATURE REVIEW}

\section{A. Reward}

These findings also suggested that although intrinsic rewards can be highly valued by employees, for some managers a combination of extrinsic and intrinsic rewards can have a positive effect on performance and motivation. But deciding on the reward package for an individual manager can sometimes prove difficult(Murphy, 2015)

\section{B. Motivation}

The motivation is an urge from within and from outside of one's self to work on a task with an as well as possible. Or in other words, the willingness of someone's efforts, encouragement and directing his behavior to carry out duties and responsibilities properly measured through indicators: earn rewards, the establishment of cooperation,

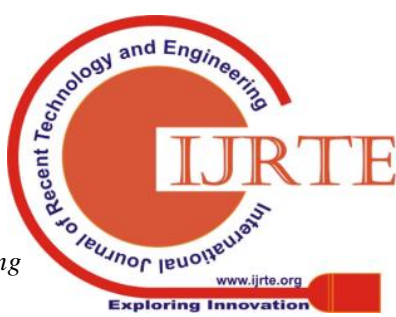


The Relationship between Reward, Work Discipline, Motivation and Employee Job Satisfaction Among Employees of Inews Tv Padang, Indonesia

respect, self-actualization and fulfillment in your work environment(Sudarno, Priyono, \& Sukmaningrum, 2016)

\section{Work Discipline}

Discipline is an attitude, behavior, and act in accordance with the company rules, either written or not.The discipline is also the awareness and willingness of a person to obey all laws and social norms. Employee discipline can be seen from the responsibility, attitude, behavior and action of an employee in compliance with all forms of regulation as long as they work at the company. Good leadership will lead to employee motivation, so with high motivation the employees will have high discipline and ultimately affect the performance of employees. Work discipline owned by employees can affect the performance. It is in line with the research conducted (Dapu, 2015)

Research Model and Hypothesis

Three important predictors of job satisfaction in this study. These predictors are reward with job satisfaction, work discipline with job satisfaction and motivation with job satisfaction. Based on the above discussion can be formulated hypothesis as follows:

H1A: Reward is positively related to job satisfaction

H1B:Reward is positively related to job satisfaction

H2A: work discipline is positively related to job satisfaction

$\mathrm{H} 2 \mathrm{~B}$ :work discipline is positively related to job satisfaction

H3A: Motivation is positively related to job satisfaction

$\mathrm{H} 3 \mathrm{~B}$ : Motivation is positively related to job satisfaction

\section{METHODS}

\section{A. Sample}

The population for this research was all of the employees in iNews Tv Padang of 15 employess. The study sample is if the subject is less than 100 , then better taken all until the research is the population.(Arikunto, 2013). In total, 15 questionnaires were distributed to iNewsTv employee. The entire questionnaire returned and filled well with an answer of $100 \%$. Furthermore, the technique of statistical analysis using multiple regression and exploratory factor analysis.

\section{B. Measurement}

The research method used is survey method. Data instrument in the form of questionnaires distributed to all employees of iNewsTvPadang. It consists of four main parts: (i) Award (ii) discipline, (iii) motivation (iv) job satisfaction. The use of a five-point Likert Scale in the study was a survey. This extrinsic reward instrument was operationally measured using three indicators, : financial rewards, interpersonal awards and promotions. (Andhika Putra Pratama, Agus Widarko, 2017). Instrument discipline can be measured through five indicators : (1) compliance with organizational rules, (2) organization fair to all employees, (3) supervision carried out at any time, (4) penalty sanction and (5) Have job responsibilities.(Cedaryana, Luddin, \& Supriyati, 2018) Furthermore, for this work motivation variable is operationally measured using four indicators,
Indicator used for motivation variable is 1). Physiological Needs 2). The Need for Security 3). Social Needs 4). Need for Appreciation. (Siahaan, 2013). Instrument of job satisfaction using an indicator with proud indicators of employment, suitability of work facilities, promotion opportunities, supervisory presence in the execution of work, and the existence of colleagues who support(Asari, 2018).

\section{RESULTS(OR RESULTS AND DISCUSSION)}

\section{A. Analysis of correlation}

Table 1 summarizes a valid demographic analysis of the 15 distributed questionnaires. The results show that the male represents the majority $(86.70 \%)$ in the sample. Based on the age of employees, in dominance aged over 31 years. In addition, most employees have a working period of 9 years

Table 1 Analysis Of Demographic

\begin{tabular}{|c|c|c|c|}
\hline \multirow{2}{*}{ Element } & & $\begin{array}{c}\text { Total } \\
\text { amount }\end{array}$ & $\begin{array}{c}\text { Percentage } \\
\text { Rate }\end{array}$ \\
\hline \multirow{2}{*}{ Sex } & Female & 2 & $13.33 \%$ \\
\cline { 2 - 4 } & Male & 13 & $86,70 \%$ \\
\hline \multirow{3}{*}{ Age } & $20-25$ & 5 & $33,33 \%$ \\
\cline { 2 - 4 } & $25-30$ & 3 & $20 \%$ \\
\cline { 2 - 4 } & $>31$ & 7 & $47 \%$ \\
\hline \multirow{2}{*}{$\begin{array}{c}\text { Working } \\
\text { Period }\end{array}$} & $1 \_5$ & 9 & $60 \%$ \\
\cline { 2 - 4 } & $>6$ & 6 & $40 \%$ \\
\hline
\end{tabular}

The Pearson Correlation Coefficient executes to test the strength and direction of the linear relationship between the predictors rewards, work discipline, motivation, and job satisfaction. (see Table 2).Correlation analysis showed that all predictors were positively correlated $(\mathrm{p}<0.01)$. The correlation coefficient of reward, discipline and motivation has a strong influence with the great job satisfaction of 0.5 The correlation coefficient of reward, discipline and motivation has a strong influence with job satisfaction that is greater than 0.5 .

Table 2 Analysis of Correlation

\begin{tabular}{|l|r|lr|lr|}
\hline Predictors & $\mathrm{X}_{1}$ & & $\mathrm{X}_{2}$ & & $\mathrm{X}_{3}$ \\
\hline Reward & 1 & $0,630^{*}$ & $0,543^{*}$ & \\
\hline Discipline & & & 1 & $0,815^{* *}$ & \\
\hline Motivation & & & & & 1 \\
\hline
\end{tabular}

\section{B. Exploratory Factor Analysis On SPSS}

Explorative factor analysis (EFA) was conducted for pre survey data, ie 45 questions from 4 predictors in the questionnaire. EFA is a statistical technique to identify the underlying factor structure for the observed variablesIt is observed that the KMO value is 0.676 and the Barlett test Sphericity results $(\mathrm{p}<0.01)$, which indicates the data in this study is feasible for the purposes of the analysis. Communal analysis explains that all item communities are greater than 0.5. This may mean that the 
entirety of the variables used to have strong relationships with factors that are formed. To determine how a component/factors which are used in order to explain the diversity of the total then is seen from the great value of the eigenvalue component with eigenvalue $1>$ is a component that is used. Because the Component 1 number eigenvalue above the number 1 but at number 2 eigenvalue component directly under the number 1 then factoring process be stopped.

Table 3 Rotated Component Matrix

\begin{tabular}{|c|c|c|c|c|}
\hline \multicolumn{5}{|c|}{ Rotated Component Matrix ${ }^{a}$} \\
\hline & \multicolumn{4}{|c|}{ Component } \\
\hline & 1 & 2 & 3 & 4 \\
\hline $\mathrm{x} 1.2$ & & & 0,460 & \\
\hline $\mathrm{x} 1.3$ & & & $\mathbf{0 , 8 2 7}$ & \\
\hline x1.4 & & & 0,650 & \\
\hline $\mathrm{x} 1.5$ & & & 0,513 & \\
\hline x1.6 & & & $\mathbf{0 , 7 3 0}$ & \\
\hline $\mathrm{x} 1.7$ & & & 0,581 & \\
\hline $\mathrm{x} 1.8$ & & & 0,842 & \\
\hline $\mathrm{x} 1.9$ & & & 0,738 & \\
\hline $\mathrm{x} 1.10$ & & & 0,517 & \\
\hline $\mathrm{x} 1.12$ & & & 0,696 & \\
\hline $\mathrm{x} 2.4$ & 0,567 & & & \\
\hline $\mathrm{x} 2.5$ & 0,876 & & & \\
\hline $\mathrm{x} 2.6$ & 0,879 & & & \\
\hline $\mathrm{x} 2.7$ & 0,879 & & & \\
\hline $\mathrm{x} 2.8$ & $\mathbf{0 , 7 0 7}$ & & & \\
\hline $\mathrm{x} 2.9$ & 0,921 & & & \\
\hline $\mathrm{x} 2.10$ & 0,685 & & & \\
\hline $\mathrm{x} 2.11$ & 0,577 & & & \\
\hline $\mathrm{x} 2.12$ & 0,722 & & & \\
\hline $\mathrm{x} 2.13$ & 0,629 & & & \\
\hline $\mathrm{x} 2.14$ & 0,902 & & & \\
\hline $\mathrm{x} 3.2$ & 0,544 & & & \\
\hline x3.9 & 0,755 & & & 0,452 \\
\hline x3.14 & 0,593 & & & 0,483 \\
\hline x3.6 & & & & 0,756 \\
\hline $\mathrm{x} 3.7$ & & & & 0,506 \\
\hline $\mathrm{x} 3.8$ & & & & 0,651 \\
\hline $\mathrm{x} 3.15$ & & & & 0,607 \\
\hline $\mathrm{y} 2$ & & $\mathbf{0 , 8 3 6}$ & & \\
\hline y3 & & $\mathbf{0 , 8 9 7}$ & & \\
\hline y4 & & 0,474 & & \\
\hline y7 & & $\mathbf{0 , 8 9 0}$ & & \\
\hline y8 & & 0,715 & & \\
\hline y10 & & 0,682 & & \\
\hline y11 & & 0,646 & & \\
\hline y12 & & 0,676 & & \\
\hline
\end{tabular}

\begin{tabular}{|c|c|c|} 
y13 & $\mathbf{0 , 6 7 6}$ & \\
y15 & $\mathbf{0 , 8 9 7}$ & \\
\hline Extraction Method: Principal Component Analysis. \\
Rotation Method: Varimax with Kaiser Normalization. \\
a. Rotation converged in 7 iterations. \\
\hline
\end{tabular}

From the table above shows that all the loading factor amount ranging from $0.414-0.917$ exceeds the threshold of 0.4 (see table 3 )

\section{Multiple Regression Analysis.}

Multiple regression analysis was conducted to test whether reward, discipline and motivation have an effect on job satisfaction. Double regression was applied to test the impact of reward, work, discipline and motivation on job satisfaction. (See Table 4). The statistical value of $F$ for the regression analysis was significant $(\mathrm{p}<0.001)$, confirming the validity of the regression model. Furthermore, the variance inflation factor (VIF) for all independent variables is less than 10, indicating no multicollinearity in the regression model. The normal P-P plot shows that all points follow and close to the diagonal line so it can be concluded that the regression model meets the assumption of normality. Table 4 Regression Analysis

\begin{tabular}{|c|c|c|c|c|}
\hline \multirow{2}{*}{ Variable } & $\begin{array}{c}\text { Unstandardized } \\
\text { coefficient }\end{array}$ & \begin{tabular}{c} 
Standard \\
\cline { 3 - 4 }
\end{tabular} & $\begin{array}{c}\text { Coefficie } \\
\text { nt }\end{array}$ & Sigh \\
\hline Reward & 0,485 & 0,311 & $\begin{array}{c}1,53 \\
3\end{array}$ & $\begin{array}{c}0,15 \\
3\end{array}$ \\
\hline $\begin{array}{c}\text { Disciplin } \\
\text { e }\end{array}$ & 0,284 & 0,333 & $\begin{array}{c}1,13 \\
6\end{array}$ & $\begin{array}{c}0,28 \\
0\end{array}$ \\
\hline $\begin{array}{c}\text { Motivati } \\
\text { on }\end{array}$ & 0,381 & 0,324 & $\begin{array}{c}1,19 \\
4\end{array}$ & $\begin{array}{c}0,25 \\
8\end{array}$ \\
\hline \multicolumn{2}{|l|}{ R square $=0,729$} & F statistic $=9,845$ & \\
\hline
\end{tabular}

\section{DISCUSSION (OR RESULTS AND DISCUSSION)}

Multiple regression analysis showed that reward, discipline and work motivation positively influence to job satisfaction which means hypothesis $\mathrm{H} 1, \mathrm{H} 2$, and $\mathrm{H} 3$ are supported. First, that the reward variable affects the job satisfaction. So how a person performs and the rewards that improves that performance will depend on what they value at that specific time of their lives(Murphy, 2015)

Second, the motivational variables affect job satisfaction which means employees will feel satisfied if the motivation of working in accordance with their expectations, is in line with research (Endo Wijaya Kartika \& Thomas S. Kaihatu, 2010) that influential work motivation variables significantly to job satisfaction of employees in Pakuwon Food Festival

Third, the variables of work, discipline have an effect on job satisfaction, meaning that work discipline is very important to be done in complying with the applicable rules and regulations. This finding is consistent with the previous research work on work, discipline simultaneously have a significant effect on employee job satisfaction(Jihan Rizki Kiay Demak, 2014; Mardiono, 
2014; Rizki Indah Kartikasari, 2017)

The standard coefficients in multiple regression are examined to identify the relative contribution in explaining the effects of rewards, discipline and work motivation. The largest beta coefficient indicates that the independent variable has the strongest contribution to the dependent variable. The results show that reward, discipline and work motivation affect job satisfaction, while of the three largest variables affecting job satisfaction is the discipline

\section{CONCLUSION AND RECOMMENDATION}

The purpose of this study is to test whether reward, discipline and motivation affect job satisfaction. This research is in line with the literature On the results of research conducted at PT. Dada Indonesia, dimensions variable frequency Attendance at Work Discipline has become a high-dimensional criteria, it gives the impression that the level of attendance of employees Level staff has been very good and need to be maintained by means of spur employees to be more disciplined present in the workplace and reduce the number of employees in the absence of any specific time (Mangkunegara \& Octorend, 2015). The results show that work discipline is the predictor that most affect job satisfaction. This shows that discipline is necessary for the company in order to achieve the goals both company goals and individual employee goals.

\section{ACKNOWLEDMENTS}

We would like to thank iNews Tv Padang and AMIK Jayanusa Padang as the parties involved in this research this research can be completed.

\section{REFERENCES}

[1] Andhika Putra Pratama, Agus Widarko, A. R. S. (2017). Pengaruh Reward dan Punishment Terhadap Motivasi Kerja Karyawan Goldia Camilan Malang. Jurnal Riset Manajemen, O(November 2016), 124-135.

[2] Arikunto, S. (2013). Prosedur Penelitian: Suatu Pendekatan Praktik. Jakarta: Rineka Cipta.

[3] Asari. (2018). The Effect of Personality, Organizational Climate and Job Satisfaction on Teachers Organizational Citizenship Behavior at Public Vocational High School in DKI Jakarta Province. International Journal of Scientific Research and Management (IJSRM), 6(4), 191-197. https://doi.org/10.18535/ijsrm/v6i4.el02

[4] Azman, I. et all. (2014). Effect of manager's role in performance based pay on employee outcomes. Global Journal Al-Thaqafah, 4(2), 41-58. Retrieved from www.gjat.my/gjat122014/6520140402.pdf

[5] Cedaryana, Luddin, M. R., \& Supriyati, Y. (2018). Influence of Work Discipline, Career Development and Job Satisfaction on Employee Performance Directorate General Research and Development of Ministry Research, Technology and Higher Education. International Journal of Scientific Research and Management, 6(2), 87-96. https://doi.org/10.18535/ijsrm/v6i2.el02

[6] Choi, S. L., Goh, C. F., Adam, M. B. H., \& Tan, O. K. (2016). Transformational leadership, empowerment, and job satisfaction: The mediating role of employee empowerment. Human Resources for Health, 14(1), 1-14. https://doi.org/10.1186/s12960-016-0171-2

[7] Dapu, V. A. W. (2015). the Influence of Work Discipline, Leadership, and Motivation on Employee Performance At Pt . Trakindo Utama Manado. Jurnal EMBA, 3(3), 352-361.

[8] Endo Wijaya Kartika, \& Thomas S. Kaihatu. (2010). Analisis Pengaruh Motivasi Kerja Terhadap Kepuasan Kerja (Studi Kasus pada Karyawan Restoran di Pakuwon Food Festival Surabaya). Jurnal Manajemen Dan Kewirausahaan, 12(1), https://doi.org/10.9744/jmk.12.1.pp. 100-112
[9] Finna Okta Maulina, Yusuf, M., \& Priyatama, A. N. (2015). Hubungan antara budaya kerja dan disiplin kerja dengan kepuasan kerja pada karyawan Bagian Umum Pemerintah Kota Tegal. Jurnal Ilmiah Psikologi Candrajiwa, 4, 235-244. Retrieved from http://candrajiwa.psikologi.fk.uns.ac.id/index.php/candrajiwa/article/vie w/116

[10] Jihan Rizki Kiay Demak, S. S. P. (2014). Employee discipline and attitude to job satisfaction in sekretariat daerah kabupaten minahasa. EMBA, 2, 298-306.

[11] Mangkunegara, A. P., \& Octorend, T. R. (2015). Effect of Work Discipline, Work Motivation and Job Satisfaction on Employee Organizational Commitment in the Company (Case Study in PT. Dada Indonesia). Universal Journal of Management, 3(8), 318-328. https://doi.org/10.13189/ujm.2015.030803

[12] Mardiono, D. (2014). Pengaruh Motivasi dan Disiplin Kerja terhadap Kinerja Karyawan. Jurnal Ilmu \& Riset Manajemen, 3.

[13] Murphy, B. (2015). Dublin Business School in association with Liverpool John Moore' $s$ Title: The impact of reward systems on employee performance A thesis submitted to Dublin Business School in partial fulfilment of the requirements for Masters of Business Administration, (May).

[14] Rizki Indah Kartikasari, I. D. (2017). Pengaruh Pelatihan dan Disiplin Kerja Terhadap Kinerja Karyawan dengan Kepuasan Kerja Sebagai Variabel Intervening. Dipoegoro Journal Of MAnagement, 6, 1-12. Retrieved from http://ejournal-s1.undip.ac.id/index.php/dbr

[15] Sari, R.F., Siburian, T.A, \& Wau, Y. (2017). The Effect of Work Discipline , Job Satisfaction and Work Motivation Towards Teacher Organizational Commitment in Smp Negeri of Medan Kota District. Jurnal of Research \& Method in Education (IOSR-JRME), 7(5), 45-54. https://doi.org/10.9790/7388-0705014554

[16] Senasu, K. ., \& Singhapakdi, A. . (2014). Relative effects of lower-order and higher-order quality of work life on employee job satisfaction and life satisfaction: Case studies of service and manufacturing sectors in Thailand. Kasetsart Journal - Social Sciences, 35(1), 73-83. Retrieved from

http://www.scopus.com/inward/record.url?eid=2-s2.0-84923683609\&p artnerID $=40 \&$ md5=7f716a59aee2136db58764b9e8e9c81c

[17] Siahaan, R. (2013). Pengaruh Reward dan Punishment terhadap Disiplin Kerja Karyawan Pada PT. Perkebunan Nusantara III Rambutan. Jurnal Ilmiah Bussines Progress, 1(1), 17-26.

[18] Sudarno, S., Priyono, P., \& Sukmaningrum, D. (2016). Effect of Compensation, Motivation and Organizational Climate on Employee Satisfaction: Study on PT. Sumber Alfaria Trijaya Tbk. in Gedangan-Sidoarjo. International Journal of Business and Management, 11(2), 212. https://doi.org/10.5539/ijbm.v11n2p212

\section{AUTHOR PROFILE}

I am Dorris Yadewani, currently I am affiliated with Information and Computer Management, AMIK Jayanusa, Indonesia, my area of research is Reward, Work Discipline, Motivation and Employee Job Satisfaction. 